\title{
Hayırsever, Dindar, Nazik ve Şâire Bir Padişah Kızı: Âdile Sultan
}

Philanthropic, Religious, Gentle and Poetry A Sultan's Daughter: Adile Sultan

\section{Arif Kolay}

\section{Öz}

Çalışmanın konusu özellikle yaşadığı uzun ömür ve şairliği ile dikkati çeken padişah kızlarından birisi olan Âdile Sultan hakkında olacaktır. Âdile Sultan İkinci Mahmud'un kızlarından biridir.

Osmanlı tarihinde İkinci Mahmud en çok kızı olan padişahlar arasındadır. İkinci Mahmud'un 40'a yakın çocuğu olmuş ve bunların dörtte biri hariç diğerleri çok küçük yaşlarda vefat etmiştir. İçlerinde Sâliha, Mihrimah, Atiye, Hatice Sultan gibi küçük yaşta ölümün pençesinden kurtulanlar oldu ise de, İkinci Mahmud'un en uzun yaşayan kızı Âdile Sultandır.

Âdile Sultan'ın, birçok farklı özelliği vardır. Osmanlı hanedanının divan sahibi ilk ve tek hanım şâiresidir. Şiirleri oldukça samimi olup, büyük bir kısmı dinî-tasavvufî bir mahiyete sahiptir.

Evlendikten sonra debdebeli bir hayat yaşayan Âdile Sultan, kocasının ve kızının vefatlarından sonra adeta inzivaya çekilmiş, gezintileri bırakmış, ibadetle, fakir fukaraya yardım etmekle vaktini geçirmiştir.

Anahtar Kelimeler: Âdile Sultan, II. Mahmud, Osmanlı Saray Kadınları

Yrd. Doç. Dr., Dumlupınar Üniversitesi, Fen Edebiyat Fakültesi, Tarih Bölümü, Kütahya, arif.kolay@dpu.edu.tr

Bu makale iThenticate sistemi tarafından taranmıştır.

Makale gönderim tarihi: 18.04.2017

DOİ: 10.17550/akademikincelemeler.306917 


\section{Abstract}

The subject of the work will be about Adile Sultan who is one of the sultan's daughters who is especially noticed with his long life and poetry. Adile Sultan is one of the daughters of Mahmud II.

In Ottoman history, the Second Mahmud is among the sultan who is the most daughter. The second Mahmud had 40 children. Most of them died at an early age. Although there were survivors of the death penalty in their early years such as Sâliha, Mihrimah, Atiye and Hatice Sultan, Sultan Mahmud's longest surviving daughter, Adile Sultan.

Adile Sultan has many different characteristics. It is the first and only wife of the Ottoman dynasty. His poems are quite sincere, and most of them have a religious-mystical place.

Adile Sultan, who has lived a life after being married, has almost gone to seclusion after leaving her husband and her daughter, leaving the journeys, worshiping and helping the poor.

Keywords: Adile Sultan, II. Mahmud, Ottoman palace women 


\section{Giriș}

Adile Sultan'n babası Sultan İkinci Mahmud, annesi ise Zernigar Kadın'dır. Sultan İkinci Mahmud, Birinci Abdülhamid ve Nakşidil Valide Sultanın oğlu olarak 20 Temmuz 1785 tarihinde İstanbul'da doğdu. Adlî mahlasını kullanmıştır. Bu mahlas doğumunda kendisine verilmiştir. Bundan başka "büyük" sıfatıyla da anılmıştır. Amcas1 III. Selim'in 29 Mayıs 1807 'de tahttan indirilmesi, ağabeyi IV. Mustafa'nın tahta çıkışı ve onun da Alemdar Mustafa Paşa tarafından hal edilmesinden sonra 28 Temmuz 1808'de Osmanlı padişahı oldu. III. Selim'in katli ile darbeler ve karşı darbelerle başlayan saltanatı hız kesmeden devam etti ${ }^{1}$.

Saltanatının ilk devresi yani Yeniçeri Ocağı'nın kaldırıldığı 1826 yılına kadarki dönemi askeri ve ilmiye sınıfi ile ayanlarca desteklenen yenilikçi cephenin karşısındakilerin tahakkümü altında geçti ${ }^{2}$. Yeniçeri Ocağı'nın kaldırılmasından sonra radikal kararlar alarak ciddi reformlar yaptı. Birçok icraatından dolayı halktan tepki aldığı da oldu. Mesela 3 Mart 1829'da çıkartıp uygulamaya koyduğu kıyafet yasası bunlardan birisiydi. Kızı Atiye Sultan'1 bile asker üniforması giydirerek Bâb-1 Seraskeri'ye ve kışlalara götürmesi tepkilere yol açmıştı. Geniş omuzlu, orta boylu, beyaz sakallı ve zarif idi. Diğer Osmanlı padişahları gibi iyi bir eğitim gördü. Zeki, bilgili, temkinli, azimli, sabırlı ve aynı zamanda cesur bir karaktere sahip idi İ İktidarı süresince devletin ayakta kalması için mücadele veren ve son dönemlerinde ciddi hastalıklara maruz kalan II. Mahmud, sağlığı ile ilgili yapılan müdahalelerden de sonuç alamayınca 28 Haziran'da vefat etti'.

1 Yeniçeri isyanları, zorbalık yapıp merkezî yönetimi sıkıntıya sokan idareciler ve âyanların hadlerinin bildirilmesi, Sırplıların ve Rumların milliyetçi ayaklanma ve isyanları, İranlılar ve Ruslarla savaşlar ve özellikle Mısır meselesi ve Mehmed Ali Paşa isyanı döneminde yaşanan önemli gelişmeler arasındadır. Bütün bunlarla birlikte köklü 1slahatlar ve devletin yeniden yapılanması saltanatının belirgin özelliğini oluşturur. Kemal Beydilli, "Mahmud II", DIA, XXVII, yıl: 2003, s. 353.

2 Beydilli, aynı makale, s. 354.

3 Abdülkadir Özcan, "II. Mahmud ve Reformları Hakkında Bazı Gözlemler”, Tarih Incelemeleri Dergisi, X, İzmir 1995, s. 13-39.

4 Sultan vasiyet ettiği üzere bugün Türbe diye bilinen ve Yeniçeriler Caddesi adı verilen mahalde medfundur. II. Mahmud'un on yedi zevcesinin olduğu bilinmektedir. Otuz 
Adile Sultan'ın annesi Zernigar kadın, Kaptan-1 Derya Hüseyin Paşa'nın eşi ve İkinci Mahmud'ın kız kardeşi Esma Sultan tarafından yetiştirilip, padişaha takdim edilmiştir. İkinci Mahmud'ın dördüncü ikbali iken Âdile Sultan'ı doğurmuş ve bunun üzerine 7. Kadınefendiliğe yükselmiştir ${ }^{5}$. 1830 yılında vefat etmiş ve Fatih'teki Nakşidil Valide Sultan Türbesine defnedilmiştir'6.

\section{Âdile Sultan'ın Doğumu}

Pek çok konuda olduğu gibi hanedan mensuplarının doğumlarında da gelenek halini alan uygulamalar olmuştur. Doğum ile ilgili süreci anlamak için bu uygulamalardan kısaca bahsetmekte yarar olacaktır.

Sultan I. Ahmed'den Sultan Abdülaziz'e kadar şehzadeler ancak tahta geçip padişah olduktan sonra çocuk sahibi olabilirlerdi. Tahttaki padişahın, kadınefendi, haseki, ikbal gibi unvanları taşıyan hanımlarından doğum vakti yaklaşan için, valide sultan veya hazinedar ustanın girişimiyle hazırlıklar yapılırdı. Haremdeki odalardan biri kırmızı renkli halılarla döşenir ve lohusa yatağı hazırlanırdı. Oda, baştan aşağıya yataklar, yastıklar, perdeler vesaire süslenerek donatılırdı. Odada ibrik, gümüş leğen, hamam tası ile duvara asılı Kuran, mücevherli nazarlıklar da bulunurdu?

Doğumu yaklaşan kadın için ihtiyaç duyulan eşyalar da bizzat valide sultan tarafından sipariş edilerek temin edilirdi. Hazinedar ve-

altı tane çocuğu olmuştur ancak büyük kısmı küçük yaşlarda hayatlarını kaybetmiştir. Vefat ettiğinde geride altı çocuk bırakmıştır. Bunların ikisi Sultan Abdülmecid, Sultan Abdülaziz'dir. Diğerleri de Hatice, Atıyye, Sâliha, Âdile'dir. Beydilli, aynı makale, s. 356; 1 Temmuz günü Divanyolu'ndaki Esmâ Sultan Sarayı'nın bahçesine defni yapılmıştır. Abdülhalim Efendi (Sultan Abdülmecid dönemi Ebniye-i Hâssa müdürü) türbenin inşasıyla görevlendirilmiştir. 5 Temmuz 1839 tarihinden sonra inşasına başlanan türbe 12 Ekim 1840'da tamamlanmıştır. Burcu Özgüven, "Mahmud II Türbesi, Sebili, Çeşmesi ve Hazîresi", DİA, XXVII, yıl: 2003, s. 357.

5 Yılmaz Öztuna, Devletler ve Hanedanlar II-Türkiye 1074-1990, C.I, Kültür Bakanlığ1, Ankara 1996, s. 126

6 M. Çağatay Uluçay, Padişahların Kadınları ve Kızları, Ankara 2001, s. 1

7 Necdet Sakaoğlu, "Beşik Alayı”, Dünden Bugüne İstanbul Ansiklopedisi, II, Haz. İlhan Tekeli vd., İstanbul 1994, s. 160. 
kili veya kethüdası talep edilen malzeme ve eşyaları defteriyle beraber düzenleyerek hareme teslim ederdi ${ }^{8}$.

Padişahtan çocuk sahibi olan kadınlar kaç çocuğu olursa olsun çocuklarıla kendilerine tahsis edilen dairede ikamet ederlerdi. Bu daireye de "bucak" denirdi. Her sultan ve şehzade kendi cariyeleriyle "ev" tabir edilen kendi dairelerinde ikamet ederlerdi. Mesela "filan sultanın evi", cariyelerine de "filan sultanın evlisi" denirdi. Taamları, kiler tayınları padişah çocuklarının evine gelir ve münferiden kendi evlerinde yemek yerlerdi. Saraylılar sultanları, şehzadeleri, kadınefendileri genellikle "devletliler" tabiriyle yâd ederlerdi?.

Padişah çocuklarının doğumuna "veladet-i hümayun" denirdi. Yeni dünyaya gelen çocuğun doğumu Darüssaade ağası tarafından Silahtar ağaya bildirilirdi. Padişaha müjdeyi Silahtar ağa verirdi. Yine doğumlar Padişah hatt-1 hümayunu ile sadrazama bildirilir, hatt-1 hümayun burada vükelâ, ulema ve diğer memurlar huzurunda okunur ve hayır dualar edilirdi. Daha sonra yapılan "rikab resmi" töreni ile başta Sadrazam, şeyhülislam ve diğer devlet adamları padişahın huzuruna çıkıp doğumu tebrik ederlerdi. Tebrik için gelen devlet adamları da padişah tarafından ödüllendirilirdi ${ }^{10}$.

Eskiden beri uygulana gelen bu gelenek üzerine, Âdile Sultan'ın doğumu bir hatt-1 hümâyun ile Hazinedar Ağa vasitasıyla Sadrazama bildirilmiştir. İsmini bizzat "Âdile" olarak koyduğunu bu hatt-1 hümayun ile belirten İkinci Mahmud, bu vesile ile doğumun halka duyurulması amaciyla üç gün üçer nevbet top atılması emrini vermiştir. Yine dipnotta günümüz Türkçesiyle çevirisi verilen hatt-1 hümayunda görüleceği üzere Âdile Sultan'ın doğumu vesilesi ile kalan “rüsum-1

8 Âdile Sultanın doğumu ile ilgili yapılan masraflar listesi Topkapı Sarayı Arşivi, Ceyb-i Hümâyûn Defteri, nr. 4/2472'de bulunmaktadır. Nihat Azamat, "Âdile Sultan" DİA, I, y1l: 1988, s. 382; Ferda Mazak, Sultan II. Mahmud'un Kızı Âdile Sultan, Çamlıca Kültür ve Yardım Vakfı Yayını, İstanbul 2000, s. 14.

9 Balıkhane Nazırı Ali Rıza Bey, Eski Zamanlarda İstanbul Hayatı, (Hazırlayan: A. Ş. Çoruk), İstanbul 2001, s. 312.

10 Ali Akyıldız, Mümin ve Müsrif Bir Padişah Kızı Refia Sultan, İstanbul 1998. 
mutâde" yani geleneksel olarak alınan vergi bir defaya mahsus olarak affedilmiştir ${ }^{11}$.

Padişah çocuklarının doğumlarıyla ilgili kutlamalar sadece İstanbul ve çevresinde değil ülkenin dört bir tarafında da Rumeli’ye ve Anadolu'ya üçer koldan fermanlar gönderilerek durum bildirilir ve tüm kadınlar, gelen haber üzerine sicile doğum kaydını geçirirler ve şehirlerde veladet şenlikleri düzenlenirdi. Diğer yandan ozanlar da doğum için, sanatsal dizelerle tarihler düşürürlerdi ${ }^{12}$. Mesela Âdile Sultan'ın doğumu için Mısır'da toplar atılarak üç gün şenlikler yapıldığı Mısır Valisi Mehmed Ali Paşa'nın gönderdiği 25 Ocak 1826 tarihli kaimeden anlaşılmaktadır ${ }^{13}$.

Âdile Sultan'ın doğumu ile ilgili Elif Naci'nin Topkapı Sarayı Arşivi kaynaklarından faydalanarak yaptığı oldukça güzel bir tasviri var. Şöyle ki;

"Tarihler 23 Mayls 1826'yll gösterdiğinde, sade sûzenî işleme beyaz Atlas yastıklarla süslenmiş dört sedirin bulunduğu bir saray odast. Odanin sekiz penceresinde ve kapısinda mavi canfes perdeler asıll. Kenarda dört çift, yine sûzenî işlemeli sarı canfesten yüz yastıkları, pamuklarla doldurulmuş iki pembe şilte. Onun üzerinde de on altı yastık daha. Bu oda Sultan İkinci Mahmud'un hareminde dünyaya

11 Benim vezîr-i gayret-semîrim, Hazreti hallâk-1 cihânın ihsân ve keremiyle işbu pazartesi gecesi sulb-i şahânemden bir kerimem züyûd-1 edâ-yı mihr ü vücud olmağla ismini Âdile sultan tesmiye edip ve sinn-i tebşir için işbu hatt-1 hümâyun-1 inâyetmakrunumu tahrir ve hazine idad kavlem ile tarafina tesyir eyledim. Cenab-1 hak kudumunu zat-1 hümâyunuma ve kâffe-i ümmet-i Muhammed ve müslimin ile bu beşâdetlerden bil cümle ibadullah hame-yâb olmak için üç gün üçer nöbet top (atılması) icrasıyla sair rüsûm-1 mutâdenin bu defalık icrasını af eylediğimi iktiza edenlere tebyin ve ifâde eyleyesin. Hak teâlâ sülale-i tâhiremizi ilâ âhir-üz-zaman bâki edip nice şehzadelerin şeref-zuhuruyla zât-1 hilâfetimi ve kâffe ümmet-i Muhammedi sürur ve şâdiye hakkâdan eyle. Âmin. BOA, HAT. 524/25608

12 Sakaoğlu, "Beşik Alayı", s. 160.

13 “.....iş̧̧bu iki yüz kırk bir senesi şevval-i mükerremenin on beşinci günü sulb-i hümâyun-1 şahâneden bir nahid nûr-1 efşân yani devletlu ismetlü Âdile sultan-1 âlişân hazretleri teșrif-i .....”, BOA, HAT. 290/17398.

14 Elif Naci doğum tarihi ile ilgili 18 Mayıs bilgisini vermiştir. Doğrusu 23 Mayıs olacaktır. Elif Naci, “Türk Sarayında Müstesna Bir Prenses: Âdile Sultan”, Hayat Tarih Mecmuası, Sayı 10, Kasım 1965. 
gelecek olan küçük sultan için hazırlanmış. Anne Zernigar Kadınefendi. Gebe olan Zernigar Kadın 1826 senesi Mayıs ayının yirmi üçüncü günü ${ }^{15}$ bir kız evlat doğuracak ve adl "Âdile Sultan" olacaktır."

Yine Elif Naci'nin belirttiğine göre tıpkı diğer doğumlarda olduğu gibi, Âdile Sultan'ın doğumunda da yapılan masraflar defterlere kaydedilmiştir. Bunlardan doğum sırasında ve sonrasında yapılan masrafları ve diğer gelişmeleri ayrıntılı olarak takip edebilmek mümkündür. Buna göre padişahın emri ile Zernigâr Kadın'a Âdile Sultan'ı doğurmak üzere iken teslim edilen eşyanın miktarı, kuruşuna varıncaya kadar masrafları, renkleri, cinsleri teker teker bu defterlerde gösterilmiştir. Mesela âdile Sultan'ın doğumu dolayısıyla bazı yerlere "ihsân-1 şâhâne” olarak 25.800 kuruş dağıtıldığı anlaşılmaktadır.

Küçük Âdile'nin boynunda pırlanta elmasla gayet ustalıkla işlenmiş bir maşallah asılı olduktan başka, süsler, pırlanta elmaslı iki zümrüt avize, bir pırlanta elmaslı kırmızı yakut avize, yine pırlanta ile bezenmiş firuze avize, bir pırlantalı horoz mahmuzu da vardır. Doğumdan sonra ise, şal takke, yirmi tülbent takke, bir şal, kundak yorganı, pamuklu fitilli tülbent entari, kol ve ayaklar için ayrı ayrı etek bezi, pamuk tülbent yorgan şiltesi, tülbent yorgan çarşafi, tülbent minder şiltesi, beyaz gezi don, al atlas minder, ceviz beşik, gümüş sübek, fitilli tülbent, donluk bezler vs. gibi yeni eşyalar sipariş edilmiştir ${ }^{16}$.

\section{Âdile Sultanın Eğitimi}

Âdile sultan daha dört yaşında iken annesi Zernigâr Kadınefendinin vefat etmesinden sonra babası, diğer çocukları gibi Âdile Sultan'ın da iyi bir eğitim almasına özen gösterir. Sultan İkinci Mahmûd, kızı Âdile Sultân'ı büyütmek üzere çocukları yaşamamış olan Nevfidan Kadın'a teslim eder. O da Âdile Sultân'1 kendi öz çocuğu gibi büyütür, yetiştirir. Mükemmel bir tahsil ve terbiye görmesini sağlar. Müşfik ve son de-

15 Çağatay Uluçay da Âdile Sultan'ın doğum tarihini 23 Mayıs 1826 olarak belirtmiştir. Bkz. M. Çağatay Uluçay, Padişahların Kadınları ve Kızları, Ankara 2001, s. 135; İkdam Gazetesinde ölümü üzerine hakkında verilen bilgide de doğum tarihi yanlışlıkla 22 Şevval 1241 (30 Mayıs 1826) olarak ifade edilmiştir. İkdam Gazetesi, 14 Şubat 1899 Salı, Beşinci sene, no:1645, s. 1.

16 Elif Naci, agm., s. 28. 
rece dindar bir hanım olan analığı, ölen çocuklarının acısını dindirmek istercesine bu öksüze kol kanat gerer ve öz evlâdı gibi muamele eder ${ }^{17}$.

Âdile Sultan sarayda özel hocalardan Kuran-1 Kerim, Arapça, Farsça, musiki ve hat dersleri alarak yetişmiştir. Devrin en meşhur hattatlarından Ebubekir Mümtaz Efendi'den yazı dersleri alarak hattat olmaya da hak kazanmıştır. Bu eğitim süreci onun edebiyat ve şiire meyletmesini sağlamıştır ${ }^{18}$. Aldığ 1 bu eğitimler hassas kişiliği ile birleşince de bir şaire sultan olarak divan oluşturan şiirler yazmıştır. Bu açıdan bakıldığında hanedan mensupları içinde divan sahibi tek kadındır ${ }^{19}$.

Küçük yaşta annesini kaybetmesi Âdile Sultan'ı derinden etkilemiştir. Annesiyle ilgili hissiyatlarını divanının "tahassürname" bölümünde şöyle dile getirir.

"Validem sevgili canım Zernigâr/ Hal u ahlâkı güzel takva şiar

Gitti dünyadan beni koydu yetim/ Meskenin ya Rabbi kıl dârü’n-naim

Esma Sultan hâletim cennet-mekân/ Ya'ni kim hemşire-i Mahmud Hân

Etmiş ihdâ dâder-i âlisine/ Hidmetinde bulunub hayli sene

Gonca ruhsârın hazân-1 mevt âh/ Soldurub cismin dahi etdi tebâh ${ }^{20 "}$

Âdile Sultan da himayesinde yetiştiği Nevfidan Kadına büyük saygı duyduğu ve sevdiği divanında dile getirdiği şiirden anlaşılmaktadır. Şöyle ki:

"Sonra oldu Nevfidan Kadın bana/Kendi evladı gibi sadık ana

Kimseye çeşmim yaşım sildirmedi/Validem olmadığın bildir$\operatorname{medi}^{21}$ "

17 Zeynep Çakır, "Şiirleriyle Tarih Yazan Bir Saraylı: Âdile Sultan”, Yeni Asya, 11 Haziran 2011.

18 Nail Bayraktar, Adile Sultan, TSM Sevenler Derneği, Sanat Tarihi Araştırmaları Semineri, İstanbul 1994, s. 6.

19 Mazak, a.g.e., s. 22.

20 Ferda Mazak, Sultan II. Mahmud'un Kızı Âdile Sultan, Çamlıca Kültür ve Yardım Vakfi Yayını, İstanbul 2000, s. 18

21 Mazak, a.g.e., s. 19. 
Âdile Sultan analığı ile ilgili hislerini bu ifadeleriyle dile getirirken, bize ise; harem kadınlarının üstün ahlâk ve faziletlerle donatılmış gerçek yüzünü göstermiş oluyordu.

Âdile Sultân annesinin vefatından yaklaşık dokuz yıl sonra da babasını kaybeder. Babası Sultan İkinci Mahmud vefat ettiğinde henüz on üç yaşına yeni girmiştir. Bu dönemde Sultan, artık hem öksüz, hem yetimdir. Yeni meskeni olan Dolmabahçe Sarayının olanca ihtişamı ve ağabeyi Abdülmecid'in himayesi bile, bu yoksunluğu gidermekten $\operatorname{acizdir}^{22}$.

Babasından sonra kendisinden dört yaş büyük ağabeyi Abdülmecid tahta çıkar. Abdülmecid de kardeşi Âdile Sultan'1 çok severdi. Onu hususi himayesine almış ve hiçbir şeyden mahrum etmemişti. Buna rağmen Sultan "İftiraknâme" adlı eserinde hislerini dile getirmiş ve babasının ölümüne tarih düşmüştü²3.

22 Çakır, a.g.m.

23 “Öyle me’yûsum ki mislim görmemişdir bu cihan / Vâlidem cânım idi hem vâlidim Mahmûd Hân

Kaldım onlardan sabiyy-i nâtüvân iken yetîm / Açdı kalb ü sîneme firkatleri zahm-1 azîm

Dâderim cennet-mekân Abdülmecid etdi cülûs / Sâye-i şâhânesinde olmuş idim nevarûs

Geçdi eyyâmın ferâğ-1 hâtır ile bir zamân / Zann ederdim ol dem-i mes'ûdı baha câvidân

Aksine devr etdi sonra işbu çarh-1 bi-vefâ / Hazret-i Abdülmecid Hân eyledi azm-i bekâa Çün bana olmuş idi hem şâh ü hem yâr u nasîr/Hem birâder hem peder hem vâlide hem destgîr

Başka bir acı da gösterdi baha zâlim felek /Ya'ni zevcim Ali Pâşâ da gitdi Adn'e dek Yadigârı kalmış idi Hayriyye Sultân bana / Kalb-i mahzûnum onunla eğlenirdi dâimâ Nûr-1 çeşmimdi surûr-1 kalb-i virânım idi / Hemdem ü yâr-i şefíküm sînede cânım idi Hüsnü hulku veş cemîl ü pek güzel idi kızım / Hayra mâ’il merhametli bî-bedel idi k1zım

Âh kim ol nevcivân ü gül-fidânım nâ-gehân / Uğradı bir derde asla bulmadı çâre aman İşte bu pür yara sînem gördü bir yara dahi / Uğradı ya'ni cefâ-yı çarh-ı gaddâra dahı Kardaşım Abdülaziz Hân Pâdişâh-1 asr iken / Adl ü lutf ü rahm ile bir tâcdâr-1 dehr iken Etdi terk-i saltanat ba-hükm-i takdir-i Hudâ / Sonra yüz gösterdi ammâ emr-i cellâd-1 kazâ

Nâ-gehân bir hâl oldu mahşer-i dünyâ gibi / Düşdü al kanlar içine gonca-i hamrâ gibi Hânedânı mâden evlâdı efgân eyledi / Hâl-i ehl-i beytini bu gam perişân eyledi 


\section{Âdile Sultan'ın Evliliği}

Adet olduğu üzere padişahlar Osmanlı saray haremindeki evlilik çăğna gelen kızları uygun bir damat bulup evlendirirlerdi. Mevcut padişah hanedana mensup kızların evlilik başta olmak üzere her türlü iaşesinin sağlanmasından sorumluydu.

Narin, orta boylu, kumral, mavi-ela gözlü bir kız olan Âdile Sultan'ın gelinlik çağına geldiğini gören ikinci Mahmud, kızını uzun boylu, yakışıklı, kabiliyetli ve çok güvendiği Mehmed Ali Paşa ile evlendirmeyi düşünür. Bunun üzerine mabeyncisi Mehmed Ali Paşa'yı huzura çağırarak, Nizip'te Hafız Mehmed Ali Paşa kumandasındaki orduyu teftişle görevlendirir. Bu görevi ifa edip döndüğü takdirde kızı Âdile ile evlendireceğini vaat eder. Hemen yola çıkan Paşa, Hafız Mehmed Ali Paşa kumandasındaki ordunun Nizip'te, Mısır Valisi Mehmed Ali Paşa'nın kuvvetlerine mağlup olduğunu öğrenerek geri döndüğünde İkinci Mahmud'un ölümüyle karşılaşır. Bu sırada Âdile 13 yaşındadır. Tahta çıkan ağabeyi Sultan Abdülmecid, kız kardeşini gayet güzel himaye eder. Birkaç yıl sonra da babasının vaadini yerine getirmek üzere o sırada Tophane Müşiri olan Mehmed Ali Paşa ile evlenmesini uygun görür ${ }^{24}$.

Aslen Rizeli olup Galata Başağası Hacı Ömer Ağanın oğlu bulunan Mehmed Ali Paşa, pek küçük yaşta İstanbul'a gelmiş ve hemşerilerinden Kaptanı Derya Papuçcu Ahmed Paşa delâleti ile Enderun'a verilmişti ${ }^{25}$.

Âdile Sultan ile Tophane-i Amire Müşiri Mehmed Ali Paşa'nın düğünü için gereken hazırlıkların yapılması ile ilgili hazırlanan 24 Mart 1845 tarihli hatt-ı hümayun padişahın başkurenası Hamdi Ağa eliyle

\footnotetext{
Hak adâlet etdi gerçi düşmânı gördü cezâ / Oldu amma ayn-1 ahvâl-i belâ-yı Kerbelâ Kurret-i ayn-1 habîb-i Kibriyânın aşkına / Yani yâ Rabbi Hüseyn-i Kerbelânın aşkına Kabrin ol merhûmların bâğ-1 cinân eyle hemân / Her birinin destgîri ola hem Fahr-i cihân

Cennetü'l-Firdevs içre bunlar etdikçe safâ / Âdile mahzûna da sabr-1 cemil eyle atâ, Erkan Akalın, "Bir Saray Sözcüsü Olarak Klasik Türk Şiiri”, Turkish Studies, 9/9, Yaz 2014, s. 183

24 Mazak, a.g.e., s. 26.

25 Ali Rıza-Mehmed Galib, Geçen Asırda Devlet Adamlarımız-I, (XVIII. Asr-1 Hicride Osmanlı Ricali), İstanbul 1977, s. 55; Mehmed Süreyya, Sicill-i Osmânî, III, (Yay. Haz. Nuri Akbayar), İstanbul 1996, s. 956.
} 
Sadrazam Mehmed Emin Rauf Paşa'ya ${ }^{26}$ verilmek üzere Bâbıali'ye getirildi ve arz odasında, vezirler huzurunda okundu ${ }^{27}$.

Hatt-1 Hümayun yayınlandıktan yaklaşık bir ay sonra 28 Nisan 1845 tarihinde yine padişahın emriyle Hırka-i Saadet Dairesi'nde bir toplantı yapılarak nikâhları kıyıldı. Şeyhülislamında hazır bulunduğu nikâh töreninde, Sultanahmed ve Ayasofya camii vaizleri de dua okudu. Merasim bittikten sonra süslü bohçalar içinde mücevherler, paha biçilmez güzel eşyalardan oluşan nişan takımı büyük bir alayla Tophane Caddesinden Çırağan Sarayına getirilerek Dârüssaâde Ağasına teslim edildi. Dügüülerinin de yaz aylarında yapılması için de ayrıca bir ferman yayınlandi.

Ertesi y1lın Şubat ayında bir hafta süren muhteşem bir dügünle evlendiler. Dügüun bugünkü Haydarpaşa Tren İstasyonunun bulunduğu yerde ve arkasındaki geniş çayırlıkta yapıldı. Burada bulunan kasırda İstanbul' daki sefirler, maslahatgüzarlar ve diğer misafirler ağırlanmış ve baloncu Komaski'nin balonu ile uçuşu seyredilmişti ${ }^{28}$.

Âdile Sultan'ın düğün merasimi, XIX. yüzyılda Osmanlı sarayında gerçekleşen en ilginç olaylardan biri olarak tarihe geçti. Evlendikten sonra Âdile Sultan'a Mimar Sinan Üniversitesi'nin bulunduğu yerdeki Neşetâbâd Sarayı tahsis edildi. Adile Sultan bazen burada bazen de Kuruçeşme'de Esma Sultan'dan kalan yalıda, Çırağan, Kandilli, Validebağı ve Kâğıthane' deki saraylarda oturdu ${ }^{29}$.

Âdile Sultan'1n Mehmed Ali Paşa ile evlenmesi ile ilgili olarak Reşat Ekrem Koçu şöyle bir rivayet olduğunu ifade eder: "Abdülmecid kız kardeşini çok severmiş, evlendirmeği ister, kimi teklif etse Âdile

26 Mehmed Emin Rauf Paşa İstanbul'da yetişmiştir. Ciddi bir eğitim almıştır. Devletin işleyişini iyi bilen bir kişidir. Sultan II. Mahmud ve Sultan Abdülmecid dönemlerinde olmak üzere toplam beş kez sadrazamlık yapmıştır. Kemal Beydilli, "Mehmed Emin Rauf Paşa", DíA, cilt: 28; s. 466.

27 İbnülemin Mahmud Kemal İnal, Son Sadrazamlar, Cilt 1, Dergâh yayınları, İstanbul 1982, s. 59; “..Hemşire-i muhteremem Âdile Sultanın bimennihi taalâ bu sene-i mübarekede icrâ-yı akd ve nikâhı tasmîm kerde-i şâhânemiz olduğundan ...”, BOA, HAT. 1642/9.

28 Mehmet Mermi Haskan, Yüzyıllar Boyu Üsküdar, III, İstanbul 2001, s. 1454.

29 Azamat, a.g.m., s. 383. 
Sultan reddedermiş. Meğer Sultan bir gün "Sandıkçı Güzeli" denilen Mehmed Ali isminde bir delikanlının methini duymuş, merak edip, dükkânının önünden geçince de bu esnaf dilberine gönül vermis... Keyfiyet hünkâra aksetmiş ve delikanlı hemen Enderun-ı Hümayuna alınmış... Itinalı bir tahsil ve terbiye devresinden sonra Âdile Sultanla nikâhları kiyılmış..." ${ }^{30}$ ".

Sadrazam, askeri erkân, nazırlar, şeyhler, müderrisler, imamlar, ilmiye sınıfı, rahipler, patrik, hahambaşı, İstanbul'daki bütün yabancı devlet sefir ve maslahatgüzarlar ve eşleri dâhil olmak üzere çok sayıda davetlinin katıldığı düğün Haydarpaşa civarında yapıldı ve yedi gün sürdü. Geceleri denizde sallar üzerinde meşaleler yakıldı, havai fişekler atıldı, Topkapı, Çırağan ve Beylerbeyi sarayları, kışlalar, karakollar, boğazın her iki yakasındaki bütün vezir ve nazır yalıları kandillerle donatıldı ve her tarafta şehrâyinler yapıldı. Dügünün yedinci Perşembe günü de Âdile Sultan, Beylerbeyi Sarayı'ndan valide sultanın sandalına bindirilerek, vükelânın beş çifte sandalları eşliğinde Kuleli Kışlası'na kadar uğurlandı ve kendisine tahsis edilen Fındıklı'daki Neşetâbad sahil sarayına getirildi ve gerdeğe bu sarayda girdi ${ }^{31}$.

Mehmed Ali Paşa Âdile Sultan ile evlendiğinde Tophane Müşiri idi. Sultanla evlendikten sonra kaptan-1 derya oldu. Bundan sonra Mehmed Ali Paşa beş kez daha kaptan-1 derya ve bir defa da bir yıl süreyle sadrazam olarak görev yaptı. Sultan Abdülaziz'in hükümdarl1$\breve{g} 1$ sırasında da 1868 yılında vefat etti. Âdile Sultan kocasını, Mehmed Ali Paşa da sultanı sevdi ve çok mesut günler yaşadılar. Sıdıka, Aliye, İsmail ve Hayriye ${ }^{32}$ isimlerinde dört çocukları oldu fakat bunlardan ilk üçü fazla yaşamadı. Hayriye Hanım bunların en uzun ömürlüsü oldu. Paşa ve sultan çocuklarını iyi yetiştirmek için çok uğraştılar fakat ecel Hayriye hanımı da genç yaşta ${ }^{33}$ henüz dört yıllık gelin iken ${ }^{34}$ yakaladı.

30 “Âdile Sultan”, İstanbul Ansiklopedisi-I, (Haz. Reşat Ekrem Koçu), İstanbul 1958, s. 216-217.

31 Elif Naci, aynı makale, s. 29-30.

32 Hayriye Hanım Sultan, Nisan 1866'da İşkordalızade Ali Rıza Bey ile nikâhlandı. 26 Temmuz 1869 da vefat etti. Eyüp'de babası Mehmed Ali Paşa Türbesine biri erkek ve diğer kız olan iki kardeşinin yanına defnedildi. Mehmed Süreyya, Sicill-i Osmânî, I, (Yayına Hazırlayan: N. Akbayar), İstanbul 1996, s. 17.

33 Çağatay Uluçay, a.g.e., s. 136.

34 “Âdile Sultan”, İstanbul Ansiklopedisi-I, (Haz. Reşat Ekrem Koçu), İstanbul 1958, s. 217. 
Paşa ile Sultanın her ne kadar birbirlerini sevdikleri ifade edilse de, belki de Abdülmecid döneminin genel havasından olsa gerek Fethi Ahmed Paşa benzeri bazı damatlar gibi Mehmed Ali Paşa'nın da çapkınlıkları ortaya çıkmıştı. Bunlar yaptıkları masraflar, saraya yakışmayacak derecede nahoş hareketleriyle halkın diline düşmüşlerdi. Olan bitenler Âdile Sultan'a kadar ulaşınca, sultan tebdil-i kıyafetle ve kiraladığ 1 farklı bir arabayla kocasını takip etmiş ve kocasının onu başka bir kadın zannederek kur yaptığına şahit olmuş fakat bir şey dememiştir.

Kocasının çapkınlığı ile ilgili anlatılan başka hikâye daha da ilginç. Şöyle ki:

"Âdile Sultan mütevazı bir insan olarak gösterişi pek sevmezmiş. Gideceği yerlere tebdil-i kıyafetle gide, şehirde kiraladiğ arabayla dolaşmayı tercih edermiş. Bir gün Hırka-i Şerif ziyareti için Eyüpsultan'a giderken Atikali civarında abdestini tazelemek zorunda kalmıs ve o semtte gözüne kestirdiği mükellef konaklardan birinin önünde arabadan inmiş, kapıyı çalmış. O zamanlar sahibini bilmediği bir eve böyle mazeretle misafir olmak ayıp saylmazmış. Konağın fevkalade süslü ve zevkli döşenmiş olduğunu, kendisine tutulan altın leğen ibrikle sırmalı havlularl ve güzel ev sahibi hanımın şık klyafetini görünce pek beğenmiş ve ikram edilen kahve ve şerbet takımlarına hayran olmuştur. Bu durum karşısında Sultan, kim olduklarını ögrenmek istemiş, ev sahibesi gayet sade ve işveli bir eda ile:

- Kapdân-ı Derya Mehmed Ali Paşa'nın zevcesiyim, demez mi?

Âdile Sultan'tn vaziyetini düşünün. Fakat bu garip ve beklenmedik iddia karşısında Sultan, ciddiyetini ve soğukkanlılığını kaybetmeden ve hiçbir şey hissettirmeden gördüğü iyi kabule güler yüzle teşekkür ederek ayrılmış. O gece sarayda kocasına en küçük bir serzenişte bile bulunmamıştır".

Kocası Mehmed Ali Paşayı derin bir aşkla seven Âdile Sultan, onu 24 sene beraber yaşadıktan sonra 27 Temmuz 1868 tarihinde kaybetmiştir. Sultandan 14 yaş büyük olan Paşa, cömert, iyiliksever biri olarak bilinirmiş. Bu ayrılık Sultanı çok üzmüştür. Paşanın ölümünün kendisini ne kadar harap ettiğini divanındaki mersiyede acıklı bir dille anlatmıştır ${ }^{35}$.

35 "Hoş idi hâlim onunla bana şefkatli idi/Bir iyal idi muhabbetli mürüvvetli idi 
Mehmed Ali Paşa ile ilgili bu konudaki rivayetlerin gerçek olma ihtimali yüksektir. Çünkü aşırı masraflar ve hanedana yakışmayan tavırlar sergileyen Paşa, defalarca padişah tarafindan azarlanmış ve tenzil-i rütbe, sürgün vs. ile cezalandırılmıştır ${ }^{36}$. Ancak devreye Âdile Sultan'ın girmesiyle bu tip cezalardan affedilmiştir ${ }^{37}$.

\section{Âdile Sultan'ın Çeyizi}

Âdile Sultan'ın çeyizine de çok itina gösterildi ve bizzat annesi tarafından hazırland1. Düğün esnasında bol bol hediye dağıtıldı ve çeyizi için 3.032.519 kuruş harcand1 ${ }^{38}$. Çeyizinden bazıları şunlardı:

Elmas, inci ve sırma işlemeli, kırmızı şal kaplı sırt samuru bir kürk, elmas ve inci işlemeli kırmızı şal entari, sırma işlemeli mavi şal entari, pul işlemeli fistıkî şal entari, pul işlemeli eflatun canfes entari, sırma işlemeli siyah entari, ipek işlemeli patiska entari ve değişik renklerde dallı atlas entariler.

Kapları inci ve sırma işlemeli çeşitli renklerde üç samur kürk, üzeri resimli pırlanta elmaslarla süslü inci ve tırtıl oyalı bir nişan çevresi, inci ve sırma ve kadife ipeği işlemeli al şaldan güvey yorganı, tararken mızıka çalan bir sakal tarağı, yüzden fazla yastık, on seccade, 93 yorgan, ikiyüzden fazla havlu, çeşitli renlerde yatak çarşafları, yüzlerce sofra, peşkir, nihâlî, yağlıklar, şerbet takımları, hamam seccadeleri, hamam şilteleri, hamam gömlekleri, peştemaller ve tülbentler.

Hepsi gümüşten tepsi, yaldızlı tas, makas, ustura, ayna ve kayışı ile berber takımı. Çeşitli desen ve renklerde kahve takımları, bardaklar,

\footnotetext{
Bir özü doğru, sözü doğru muhibbi devlet/Öyle bir yar için Âdile ağlar elbet. Bir Mehmet Ali Paşa idi o dünyada/Şad ede ruhunu Mevlâ mele-i âlâda Kimsenin canını yakmak ona gayr-i imkân/İntikam alma ise müşkil ve ihsan-âsân Bir Mehmet Ali Paşa idi ol dünyada/Şimdi hâk (toprak) içre veli mertebesi alâda Sandım onunla ömrüm dertsiz geçer/Hatırımdan onun gitmez idi hiç ayrılı̆̆ Neyleyem böyle imiş Hüda emri, kaderin hükmü/Yanarım ayrılık ateşi ile haşre kadar Bir Mehmet Ali Paşa idi ol dünyada/Kendisi sonsuzluğa gitti, koydu beni tenhâda Devlet ü dine sadâkatle ederdi hizmet/Emri peygamberîyi icrâya kılurdı gayret Bir özü doğru, sözü doğru muhibb-i devlet/Öyle bir yâr için Âdile ağlar elbet Bir Mehmed Ali Paşa idi ol dünyada/Vechini göstere Allah âna ukbâda”, Mazak, a.g.e., s. 38. 36 Mazak, a.g.e., s. 35.
}

37 Balıkhane Nazırı, a.g.e., s. 393.

38 Çağatay Uluçay, a.g.e., s. 136. 
buhurdanlar, billur tabaklar, şamdanlar, sabunluklar, kandillikler, gümüş leğen ibrikler, gümüş yemek tepsileri, sahanlar, maşrapalar, sandıklar, çekmeceler, fenerler, faraşlar, mercan saplı yemek kaşıkları ve daha niceleri ${ }^{39}$.

\section{Sultanın Şairliği}

Âdile Sultan, birçok farklı özelliği yanında Osmanlı hanedanının divan sahibi ilk ve tek hanım şâiresidir. Şiirleri oldukça samimidir. Sultan Abdülaziz için yazdığı mersiyede padişahın katline şahitlik ettiğini ifade etmiştir. Dedesi Kanuni Sultan Süleyman'a ait divanın basımını yaptırmakla edebiyat dünyamıza büyük hizmeti olmuştur.

Âdile Sultan'ın şiirlerinin büyük bir kısmı dinî-tasavvufî bir mahiyete sahiptir. Münâcât, mersiye, naat, Ehl-i beyt ve ashap ile tarikat kurucularının methiyelerinden oluşan bu şiirlerinden başka, kocası, babası, kardeşleri ve kızı için yazdığı şiirler de divanında geniş bir yere sahiptir. Kendisinden evvel vefat etmiş olan hânedan üyeleri için yazdığ 1 "İftiraknâme" ve "Tahassürnâme" gibi manzumelerde de hoş parçalar vardır ${ }^{40}$.

Divanında yer alan "İftiraknâme" ve "Tahassürnâme" başlıklı şiirleri adeta bir mersiyeler dizisidir ki bu, klasik mersiyelerin içerik yapısının dışındadır ve orijinal bir yapısı vardır. Nitekim yukarıda isimleri geçen saray mensuplarının hepsini bu şiirlerinde hayırla yâd etmektedir. Hayatta olmayışları ile ilgili üzerindeki etkileri bu şiirlerde okuyucularla paylaşmıştır. Örneğin Tahassürname'de Allah'ın büyüklüğü ve Peygamber efendimizi övgüsünden sonra babası İkinci Mahmud'dan bahsederek esas mevzuya şöyle geçiş yapmışıtır ${ }^{41}$.

"Otuzuncu pâdişâh Mahmûd Hân

Vâlidim ol mefhar-1 Osmâniyân

Bin iki yüz yirmi üçde oldu şâh

Etdi din ü devleti hıfz ü nigâh

39 Elif Naci, aynı makale, s. 30-31.

40 Azamat, a.g.m., 383.

41 Erkan Akalın, "Bir Saray Sözcüsü Olarak Klasik Türk Şiiri”, Turkish Studies, 9/9, Yaz 2014, s. 182. 
Elli beşde eyledi azm-i Na' îm

Millet ü evlâdını koydu yetîm"

Görüleceği gibi bu şiir aynı zamanda bir tarih risalesi vazifesi de görür. Şiirde Âdile Sultan bir gül bahçesindeki çiçekler kadar güzel ve kıymetli kardeşlerinden bahisle bazılarının babasından önce kimisinin de sonra vefat ettiği bilgisini vermektedir ${ }^{42}$.

"Bir gülistân hâsılı güller idi

Lâle vü reyhân ü sünbüller idi

Kimi ma'sûm kimi âkil kimi genc

Kimi gitdi kimi kaldı ehl-i renc

Gördü çoğu acisın ol pâdişâh

Ba'zısı fevt-i pederde etdi âh"

\section{Âdile Sultan Divanından Örnekler}

\section{Naa'tından bir dörtlük:}

'Yüzün mir'at-1 zât-1 kibriyâdır yâ Resûlallah

Vücûdun mazhar-1 nûr-1 Hudâdır yâ Resûlallah

Kabul eyle ânı aşkından âzâd eyleme bir an

Kapanda Âdile kemter gedâdır yâ Resûlallah"

Vefat eden sultanlara mersiye söylemek hususunda saray ricali arasında belki de en fazla sözü olan kişi Âdile Sultan olmuştur. Divanında gerek babası İkinci Mahmud ve gerekse kardeşleri Abdülaziz, Abdülmecid, Mihrimah, Saliha, Atıyye ve Hadice, annesi Zernigâr Sultan, halası Esma Sultan, eşi Mehmed Ali Paşa ve kızı Hayriyye Sultan için ziyadesiyle içli şiirler yazmıştır. Bunlardan biri de "Mersiye der hakk-1 cennet-mekân Sultân Abdülaziz Hân" başlığını taşımaktadır ${ }^{43}$.

Sultanın şiirleri arasında tasavvufi parçalara da tesadüf edilir. "On iki pir” hakkında medhiyeler yazmıştır. Özellikle Şah-1 Nakşıbend’e

42 Akalın, a..g.m., s. 183.

43 Erkan Akalın, "Bir Saray Sözcüsü Olarak Klasik Türk Şiiri”, Turkish Studies, 9/9, Yaz 2014, s. 182. 
karşı derin bir hürmet hissi taşıdığı görülmektedir. Yine hece vezniyle ve Yunus ilâhileri tarzında manzumeler de kaleme almıştır ${ }^{44}$.

Âdile Sultan'ın bazı şiirleri de bestelenmiştir. Sultan'ın şiirlerinden bir kısmı Şehnaz, Hüzzam ve Hicaz makamında bestelenmiştir. Kanuni Sultan Süleyman'ın şiirlerinden oluşan Muhibbi Divanı 1890 yılında ilk defa Âdile Sultan tarafından bastırılmıştı ${ }^{45}$.

\section{Sultan'ın Manevi Dünyası ve Hayırseverliği}

Âdile Sultan, kocasının sağlığında iken debdebeli bir hayat yaşamıştı. Fakat kocasının ve kızının vefatlarından sonra evine çekilmiş, gezintileri bırakmış, ibadetle, fakir fukaraya yardım etmekle vaktini geçirmiştir. Sağlığında 14 vakıf kurmuştur ${ }^{46}$. Kurmuş olduğu vakıflarla hem sağlığında hem de vefatından sonra insanlara faydalı olmuştur.

Sultan Abdülaziz zamanında kendisine misafir olan Leyla Saz Hanım Âdile Sultanı, efendi, dindar, hayırsever, fukarâperver, nazik ve beşuş olarak tanımlamaktadır. Sonraları eşi ve çocuğunu kaybettikten sonra çok üzülmüş, dünyanın hiçbir şeyini görmez olmuştur. Misafirlerine ve hizmetinde bulunanlara karşı iltifatına devam etmekle beraber, ibadet, hayır ve hasenattan başka bir şeyle meşgul olmak istememiştir. Fakir fukaranın evlerini tamir ettirir, mekteplerin ihtiyaçlarını giderir, çocukların mektebe başlamasına ön ayak olur, gelinlik kızlara çeyiz yaptırır, hastaları olanlara yardım eder, kurumuş çeşmelere su getirtir, kuyular kazdırır, hâsılı ihtiyacı olanlara yetişmeye çalışırd1 ${ }^{47}$.

Âdile Sultan'ın sık sık Eyyüb'el-Ensari'nin türbesini ziyaret ettiği arşiv belgelerinden anlaşılmaktadır. Mesela 20 Ekim 1890 Pazartesi günü saat altı civarında Eyüp Sultan türbesine ziyaret etmiş ve ziyaretten sonra orada bulunan karakola uğrayarak görevlilere ihsanda bulunmuştur ${ }^{48}$.

44 Mazak, a.g.e., s. 59; Hikmet Özdemir, "Âdile Sultan'ın Şairliği ve Edebî Kişiliğì”, http://www.hikmetozdemir.com.tr.

45 Mazak, a.g.e., s. 59.

46 Bayraktar, a.g.e., s. 5.

47 Çağatay Uluçay, a.g.e., s. 137.

48 BOA, Y.PRK.ZB. 6/49. 
Yine 2 Kasım 1890 Pazar günü Âdile Sultan Eyüb Sultan, Nakşidil Valide Sultan ve Fatih Sultan Mehmed türbelerini ziyaret etmiş ve gittiği yerlerde bulunan jandarma ve polislere hediyeler vermiştir ${ }^{49}$. Benzer şekilde 4 Kasım 1892 tarihinde Eyüp Türbesini ziyaret ettiği ve orada bulunan askerlere dağıtılmak üzere paralar verdiği arşiv belgelerinden anlaşılmaktadır ${ }^{50}$.

Âdile Sultan sık sık şehirde dolaşır, yakın çevresindeki kadın ve kızları da alarak mesire ve temâşa mahallerine giderdi. Böylece onların İstanbul'un güzelliklerini, boğaziçini, yalıları tanımalarını sağlardı. II. Mahmud'dan sonra Abdülmecid'in getirdiği yeniliklerle aynı tarihlere rastlayan bu gezintiler, bazı çevrelerce pek hoş karşılanmasa da Âdile Sultan'ın dindarlığı ve ağır kişiliği, bunların tepkilerini ortaya koymalarını engellemiştir ${ }^{51}$.

Hayriye Hanım Sultan'ın vefatından sonra, yine hizmetinde bulunanlara ve misafirlerine karşı kibarca muamelede bulunmakla birlikte, artık gezintilere pek çıkmıyordu. Baharda Silahtarağa köşküne, yazın da Vâlidebağındaki köşküne giderdi. Bu yolculuk sırasında araba vapurunun kaptan ve tayfasına, iskele memurlarına, yol üzerindeki karakol görevlilerine, önceden hazırlanan çıkınlarla, ihsanlar dağıttırır ve yoldaki fukaranın hepsine sadaka verirdi. Yukarıda örnekleri verildiği gibi Türbe ziyaretlerinde de bu manzara tekrarlanırdı. Kendini hayır işlerine ve ibadete vakfetmişti. Fukara evlerini ve mekteplerini tamir ettirir, çocuklarını mektebe başlatır, gelinlik kızlarına çeyiz yaptırır, hastalarına baktırır, kurumuş çeşmelere su getirtir, susuz yollara kuyu kazdırırdı. Böylece haberdar olduğu ihtiyaç sahiplerinin imdadına yetişmeye çalışırd $1^{52}$.

Yukarıda da ifade ettiğimiz gibi Âdile Sultanın kurmuş olduğu vakıflar hem sağlığında hem de vefatından sonra insanlara faydalı

49 BOA, Y.PRK.ZB. 10/76.

50 BOA, Y.MTV. 70/72.

51 Ferda Masak, “Âdile Sultan'ın Üsküdar'da Yaşadığı Mekânlar, Vakıfları ve Bugünkü Durumları”, Üsküdar Sempozyumu-I, Cilt II (Edt: Zekeriya Kurşun vd), İstanbul 2004, s. 125.

52 Masak, a.g.m., s. 126. 
olmuştur. Mesela 11 Mart 1923 tarihli Türkiye Büyük Millet Meclisi, Şeriye ve Evkaf Vekaleti'nden İcra Vekilleri Heyet-i Riyasetine gönderilen yazıda Anadolu'da milli Mücadele döneminde düşman tarafından yakılan, yıkılan ve harap edilen bazı köylerin mektep, mescit ve evlerinin tamiri için Âdile Sultan Vakfından 100.000 kuruş para ayrılmış ve bu para Hilal-i Ahmer vasıtasıyla ilgili yerlere ulaştırılmıştır ${ }^{53}$.

Âdile Sultanın ölünceye kadar terk etmediği bir adedi de Muharrem aylarında kazanlarla aşure pişirtip halka dağıttırmasıydı. Ramazan ayının son günlerinde de Hazreti Halid Türbesinde "Kadınlar Mescidi" olarak adlandırılan bölümde itikâfa girerdi ${ }^{54}$.

\section{Âdile Sultanın Vakıfları ve Hayratları}

Âdile Sultanın vakfettiği mal ve mülkü, bunların kimler tarafından ve ne şekilde tasarruf olunacağının şartlarını belirten vakfiyeleri, İstanbul Üniversitesi Nadir Eserler Kütüphanesinde, Türkçe Yazmalar arasında 4993 numara ile kayıtlıdır. 88 varak olan eserde bulunan ve 14 bölümden meydana gelen vakfiyede her bölümde ayrı bir vakıf ve şartları yer almakta, her bölümün son kısmında tescil tarihi, şahitlerin adları ve mühür bulunmaktadir ${ }^{55}$.

Âdile Sultan'ın menkul, gayrimenkul ve nakit para olarak vakfettiklerinden başka vakfiyede mektep, sarnıç, çeşme, kuyu, dergâh, türbe gibi yapıların ismi geçmekte ve buraların çeşitli ihtiyaçları için harcanmak üzere ayrılmış fonlar bulunmaktadır. Sultanın İstanbul'daki hayratlarından bazıları şunlardır:

- Dudullu'da babası İkinci Mahmud'un ruhunu şâd için bir çeşme ve bir namazgâh. Dudullu'daki bu namazgâh esasında, 18. yüzyılda yapılmış bir çeşmenin arkasındadır. 1730' da Hafız Abdülkerim Ağa'nın banisi olduğu çeşme, 1886-1887 yılında Âdile Sultan tarafından bakımı yaptırılmış olduğundan onun adıyla anılır ${ }^{56}$. Dudullu'nun

53 BCA, 30-10-0-0_198-355-6.

54 Bayraktar, a.g.e., s. 8.

55 Sultanın vakfettiği nakit, menkul ve gayrimenkullerle ilgili dana geniş bilgi için bkz. Mazak, a.g.e., s. 79 vd.

56 Suat Erginer, Asya'nın Kapısı Üsküdar, İstanbul 1966, s. 82. 
esas meydanında trafiği engellediği gerekçesiyle 1986 'da çeşmenin yeri değiştirilmiştir ${ }^{57}$.

-Beylerbeyi’nde Bedevi Degahında annesi Zernigar Kadınefendi ruhuna bir sarnıç.

-Kızıltoprakta, Zühtüpaşa Sokağında kızı Hayriye Hanım Sultan ruhu için bir kuyu.

-Üsküdar, Validebağı karakol binası yakınında ve Haydarpaşa' da Yeldeğirmeninde birer kuyu.

- Babası İkinci Mahmud'un sık sık ziyaret ettiği Galata Mevlevihanesinin avlusunda bir sarnıç ve üzerinde bir şadırvan.

-Eşi Mehmed Ali Paşa ruhuna Galata'da Arap Camii avlusunda bir sarnıç ve şadırvan.

-Silivrikapı dışında Seyyid Nizam Türbesinde bir sarnıç ${ }^{58}$.

-Küçükmustafapaşa' da ${ }^{59}$ Galata' da birer mektep ${ }^{60}$.

\section{Âdile Sultan’a Verilen Şefkat Nişanı Beratı}

Osmanlılar'da ilk dönemlerden itibaren başarılı kimselere nişana benzer şekilde, fakat ondan daha değerli olarak çelenk, sorguç, avize, tuğ, gibi hediyeler takdim edilirdi. Üstün hizmeti görülen mülkî ve askerî erkâna farklı dereceleri olan bir madalya verilmesi geleneği ise Batı etkisiyle II. Mahmud saltanatında başladı. II. Mahmud devrinde 1812 'de eski tip nişan ve taltif alâmetlerine son verilmesinden sonra Yeniçeri Ocağı'nın lağv1 ve yeni askerî sistemin tesisi nedeniyle rütbeleri belirtmek amacıyla nişanlar oluşturuldu. Osmanlılarda Batı tarzında ilk nişan 1852'de Mecîdî nişanı ile ihdas edildi ve iftihar nişanı

57 Semavi Eyice, “Âdile Sultan Namazgâhı”, Dünden Bugüne İstanbul Ansiklopedisi, I, Haz. İlhan Tekeli vd., İstanbul 1993, s. 84.

58 Seyyid Nizam zaviyesi 188 yılında Âdile Sultan tarafından yeniden inşa ve ihya ettirilmiştir. Hatta inşaat tamamlandıktan sonra açılış töreninde bizzat Sultan hazır bulunmuştur. Balıkhane Nazırı, a.g.e., s. 72.

59 Fatih İlçesi, Küçükmustafapaşa Mahallesi, Vakıf Mektebi Sokağında, kiliseden camiye dönüştürülen Gül Camii’nin karşısındadır. Âdile Sultan tarafından 1868 yılında yaptırılan bina 1969'dan beri kütüphane olarak kullanılmaktadır. Bazı onarım ve tamirler görmüş olmasına rağmen özgün biçimini koruyabilmiştir. M. Baha Tanman, "Âdile Sultan Mektebi”, Dünden Bugüne İstanbul Ansiklopedisi, I, Haz. İlhan Tekeli vd., İstanbul 1993, s. 83.

60 Bayraktar, ag.e., s. 8; Mazak, a.g.e., s. 108 vd. 
lağvedildi ${ }^{61}$. Yine Sultan Abdülaziz zamanında 12 Aralık 1861 tarihli nizamnâmeyle nişân-1 Osmânî çıkarıldı. Bu nişanın Mecîdî nişanından bazı farklılıkları vardı.

İkinci Abdülhamid'in saltanatı yıllarında daha evvelki nişanların kullanılmasına devam edildi. Fakat İkinci Abdülhamid kadınlara verilmek amacıyla yeni bir nişanın ihdas edilmesini zaruri görüyordu. Bunun gerçekleştirilmesinde de Batı'daki emsallerinin etkisi olmuştur. "Şefkat nişanı" tabir edilen bu nişan 16 Temmuz 1878 tarihli bir nizamnâmeyle kamuoyuna tanıtıldı. Nişanın savaş zamanlarında, yangınlarda, deprem, sel ve su baskınları gibi doğal afetlerde millete ve devlete hizmeti olan kadınlara verileceği ve üç rütbeden ibaret olacağı Nizamnâmenin beşinci maddesinde belirtilmişti. 17 Aralık 1878 tarihli iradeyle de nişân-1 âlî-i imtiyâz çıkarıldı. Bu nişan da askeri, mülki ve ilmiye sınıflarında önemli hizmetleri görülenlere verilecekti. İkinci Abdülhamid, bunların dışında 30 Ağustos 1893 tarihli irâde ile Hânedân-1 Âl-i Osmân Nişanı ihdas etti ${ }^{62}$.

Sultan Mehmed Reşad, 17 Mayıs 1910 tarihinde maarif nişanı çıkardı. Üç rütbeli olan nişan kaydıhayat yani hayatta kalmak şartıyla veriliyordu. $\mathrm{Bu}$ nişan maarifle alakalı işlerle uğraşanlara, bilim ve sanat alanında muvaffakiyet gösterenlere yönelikti ve üç rütbesi gümüştendi ${ }^{63}$. İkinci Abdülhamid döneminde sadece kadınlara verilmeye başlanan "şefkat nişanı" devletine ve milletine önemli hizmetlerde bulunan olarak Âdile Sultan'a da verilmişti. Bununla ilgili berat 18 Ocak 1879 tarihini taşıyordu ${ }^{64}$.

\section{Âdile Sultanın Yaşadığı Mekânlar}

Âdile Sultan çocukluk çağını Dolmabahçe Sarayı'nda, gençlik dönemlerini de Beylerbeyi Sarayı'nda geçirmiştir. Fındıklı Neşetâbâd Sarayı'na gelin olarak giden Sultan, daha sonraları yazlık ve kışlık de-

61 Bu nişanla alakalı olarak 29 Ağustos 1852 tarihinde bir nizamnâme yayımlandı. Nizamnamede nişanın birden beşe kadar sıralı rütbeden oluştuğu ifade edilmişti. İbrahim Artuk, "Nişan", DIA, XXXIII, yı1: 2007, s. 154-156

62 Artuk, a.g.m., s. 154-156.

63 Artuk, a.g.m., s. 154-156.

64 BOA, Y.PRK.A. 2/34. (24.M.1296). 
ğişik mekânlarda hayatını devam ettirmiştir ${ }^{65}$. Bu mekânlar şunlardır:

\section{Hüsrevâbâd Kasrı (Silahtarağa Çiftliği)}

Silahtarağa'dan Alibeyköy'e giderken köye bir kilometre kadar mesafede Sultan IV. Mehmed'in yaptırdığı ve daha sonra yıkılan saray yerine Âdile Sultan bir köşk yaptırmıştır. Bu köşke şairler Hüsrevâbad demişlerdir. 1946'lara kadar harabesi duran köşkten günümüzde bir şey kalmamıştır ${ }^{66}$.

\section{Âdile Sultan Kasrı (Validebağı Köşkü)}

Validebağı' 'ndaki yazlık köşk, Koşuyolu ile Altunizade ${ }^{67}$ arasında bulunan korunun içindedir. Korunun etrafı yüksek duvarla çevrilidir ve beş kapısı vardır. Cümle kapısı, Koşuyolu üzerinde ve Hava Lojmanlarının karşısındadır ${ }^{68}$.

Kasır, Sultan Abdülaziz tarafından kız kardeşi Âdile Sultan için 1853 yılında yaptırılmıştır. Kasır, kâgir olup bodrum kat üzerine iki katlı yapılmıştır. Kasrın oldukça geniş bir bahçesi vardır ve bahçesinde yine Sultan Abdülaziz tarafından yaptırılmış bir av köşkü bulunmaktadır ${ }^{69}$.

Kasır, hem Âdile Sultan ismiyle hem de Valide Bağı adılla anılmaktadır. Kasrın yerinde, Validebağı ismiyle anılan bu geniş ve büyük arazi parçası Sultan III. Selim'in imamı Derviş Mehmet Efendi'ye ait idi. Derviş Mehmed Efendi Hünkâr imamı namıyla anılırdı. Sultan Selim, Sarıkaya Mevkii'nde annesi Mihrişah Valide Sultan için bir

65 Mazak, a.g.e., s. 60.

66 Mazak, a.g.e., s. 61.

67 Üsküdar'ın en bilinen semtlerinden biri olan Altunizâde, ismini XVI. yüzyılda İstanbul'a yerleştiği düşünülen ve nesli hâlâ devam eden bir aileden alır. Altunizâde ailesi mensuplarından mahalleye ismini vermek şansını yakalamış olan şahıs ise, XIX. Yüzyılda yaşamış, mal varlığının önemli bir kısmını devleti ve milleti için harcamasıyla ünlü ve aynı zamanda ailede Altunizâde lakabını ilk kullanan şahıs olan İsmail Zühdü Paşa'dır. Tufan Buzpınar, "Altunizâde Ailesi”, Üsküdar Sempozyumu, IV, cilt:2, Edt. Coşkun Yılmaz, İstanbul 2007, s. 485.

68 Mehmet Mermi Haskan, Yüzyıllar Boyunca Üsküdar, III, İstanbul 2001, s. 1450.

69 Afife Batur, “Âdile Sultan Kasrı”, Dünden Bugüne İstanbul Ansiklopedisi, I, Haz. İlhan Tekeli vd., İstanbul 1993, s. 83. 
"Saray-1 âli” ve prevantoryumun olduğu kısımda da bir bağ köşkü yaptırmışt1. Bu köşk sonradan Sultan Abdülmecid'in uhdesine geçmiş o da burayı annesi Bezmialem Valide Sultan'a hediye etmişti”. Bezmialem Valide Sultan, kısa zamanda burada farklı yerlerden farklı cinslerde getirterek diktirdiği elma, armut, üzüm, vişne, dut vs. ağaçlarla büyük bir bağ kurmuştu. Bu faaliyetlerden dolayı Valide Bağı'nın ismini Abdülmecid'in annesi Bezmialem Valide Sultan'dan ${ }^{70}$ aldığı da rivayet edilir ${ }^{71}$.

Bir ara bu geniş arazi ve köşk, Altunizade İsmail Paşa'nın tasarrufuna geçmişse de Sultan Abdülaziz tarafından geri alınarak şimdiki kargir kasır yapıldı. Bu kasır, 1845'te evlenen Âdile Sultan'a 1863 tarihlerinde yazlık saray olarak verildi. Âdile Sultan, eşi Mehmed Ali Paşa ile bu köşkte yazları bir kaç ay oturmak için gelirlerdi. Bu gelişlerde ve dönüşlerde karakollara, bekçilere, fakirlere altınlar dağıtırlard1. Burada uzun yıllar oturan Âdile Sultan 1899'da vefat etmiş ve kasır, bir müddet boş kaldıktan sonra Sultan Reşad'ın (909-1918) üçüncü kadını Dürrualem Kadın'a hava değişimi için verilmiştir. Dürrualem Kadın, 17 Ekim 1909'da burada vefat etmiştir ${ }^{72}$.

Âdile Sultan Kasrı, diğer pek çok kasır, köşk ve saray gibi cumhuriyetin ilanından sonra Milli Eğitim Bakanlığı'nın kullanımına geçti. Kasır, önce darüleytam (Yetimler Yurdu) olarak hizmet vermiş; 1927 y1lında çocuk prevantoryumu olarak yeniden düzenlenmiştir ${ }^{73}$. Günümüzde de Âdile Sultan Öğretmenevi ve Kültür Merkezi olarak kullanılmaktadır ${ }^{74}$.

\section{Neşetâbâd Sahilsarayı (Hatice Sultan Sarayı)}

Beşiktaş ilçesinde, Defterdar Burnu'nda bulunan bu saray Sultan III. Ahmet tarafından yaptırılmış ve 1726 yılında tamamlanmıştır. III.

70 Valide Sultan İkinci Mahmud'un ikinci kadını olup 2 Mayıs 1853 tarihinde vefat etmiştir.

71 Haskan, a.g.e., s. 1450.

72 Haskan, a.g.e., s. 1454.

73 Afife Batur, “Âdile Sultan Kasrı”, Dünden Bugüne İstanbul Ansiklopedisi, I, Haz. İlhan Tekeli vd., İstanbul 1993, s. 83.

74 Mazak, eg.e., s. 61. 
Ahmet'in baş kadını Emetullah Kadın'dan doğan kızı Fatma Sultan'ın (1704) ikamet ettiği bu saray, Lale Devri'nin Neşatabad Sarayı'dır ${ }^{75}$. Daha sonra tahta geçen padişahlardan III. Selim'in de bu sarayı kullandiğı olmuştur.

Sultan III. Selim Neşetâbat Sarayı'nı kardeşi Hatice Sultan'ın ikameti için tahsis etmiştir. Hatice Sultan burada hayatını geçirmiştir. Sultanın Avrupa mimarisi ve süslemelerine yakın ilgisi vardı. Bundan dolayı Büyükdere'de Danimarka Maslahatgüzarı Baron dö Hubş'un tavsiyesi ile Alman as1llı mimar ve ressam olan Melling ${ }^{76}$, Hatice Sultanın hizmetine girmiş, Neşetabad sarayında yaşamış bu sarayı dekore etmiş ve yan tarafina, garp üslûbunda bir kısım ilâve etmiş, ayrıca bahçeyi de garp tarzında yeniden tertip eylemiştir ${ }^{77}$.

Hatice Sultan kardeşi III. Selim'in tahttan indirilmesinden sonra da bu sarayda yaşamaya devam etmiş ve 1821 yılında Sultan II. Mahmud zamanında burada vefat etmiştir. Neşetâbâd Sarayı, evlendikten sonra da Âdile Sultan'a tahsis edildi ${ }^{78} .1845$ y1lında gelin geldiği bu sarayda 1866 yılına kadar kışlarını geçirmiştir ${ }^{79}$.

\section{Kandilli Sarayı (Âdile Sultan Sarayı)}

Saray, Sultan Abdülmecid tarafından kız kardeşi Âdile Sultan için Tophane Müşiri Halil Paşa'dan satın alınan konağın yerine Sultan Abdülaziz tarafından inşa ettirilmiştir. 1876'da yapılan sarayın mimarı Sarkis Balyan'dir.

Kandilli'de Akıntıburnu sırtlarındaki düzlükte bulunmaktadır. Sarayı çevreleyen koruluğa sahil yolundaki kapısından girilir. Tepeye

\footnotetext{
75 Fatma Sultan, evvela Şehit Ali Paşa, sonra da Sadrazam İbrahim Paşa ile evlendi. İbrahim Paşa, Patrona Halil İsyanı'nda öldürüldü. Onun ölümünden üç yıll sonra da Fatma Sultan da vefat etti. Özlem Atalan, "Ortaköy-Kuruçeşme Arasındaki Sahilsaraylar; 19. Yüzyıl”, Turkish Studies International Periodical For The Languages, Literature and History of Turkish or Turkic Volume 10/1 Winter 2015, s. 94.
}

76 Murat Kutlu, “Avrupalıları Hayran Bırakan Neşetâbâd Sarayı”, Star Gazetesi, 07.12.2014.

77 Haluk Y. Şesuvaroğlu, “Garp Kaynaklarına Göre Boğaziçi”, Cumhuriyet Gazetesi, 05.10.1961.

78 Azamat, a.g.m., s. 383.

79 Mazak, a.g.m., s. 62. 
dolanarak çıkan yoldan sonra saraya varılır. Bina, uzun bir dikdörtgen kitle olarak kayalık ve eğimli bir arazi üzerine yerleştirilmiştir ve elli beş odası vardır. Planı şematik olarak üç bölümden oluşur. Âdile Sultan'a ait olan Batı bölümü yüksek bir subasman üzerindedir. Dış görünüşü bakımından, çok sade bir düzenlemeye sahip olan sarayın içinde yer aldığı koruda bazı müştemilat yapılar da vardı. Sarayın arkasında bulunan ve ilk işlevi bilinmeyen bina, kütüphane ve yemekhane olarak kullanılmıştır. Sarayın doğusundaki seyis ve aşçı yatakhanesi günümüzde mevcut değildir. Saray, 1916 yılında Kandilli Âdile Sultan İnas Mekteb-i Sultanisi adıyla okula dönüştürüldü̈ ${ }^{80}$.

İkinci Meşrutiyetin (1908) ilanından sonra batı tarzında, bilhassa onların memleketimizde bulunan Kız ve Erkek Mektepleri derecesinde, hatta o mekteplerden üstün mektepler açmak azim ve gayretleri yer yer belirdiği sırada İstanbul'da bir Kız Mektebi açılması fikri de ortaya çıkmıştı. 3 Kânunusani 1323 tarihli Tanin gazetesinde bu konu gündeme getirilmiş ve böyle bir okulun açılmasına şiddetle ihtiyaç duyulduğu ifade edilmişti. Bu konuda yapılan çalışmalar sonucunda padişah Mehmed Reşad Kandilli üzerindeki merhume Âdile Sultan sarayını "evvelce bir kızıma mahsus idi, şimdi bütün kızlarıma mahsus olsun" diyerek inas mektebi olarak kullanılmak üzere tahsis etmişti ${ }^{81}$.

Cumhuriyetin ilk y1llarında darüleytam olarak kullanılan bina bir ara çocuk prevantoryumuna dönüştürülmüştür. Bazı değişikliklerden sonra 1931'de Kandilli Kız Lisesi ismi ile hizmet verdi. 19661967 'de sarayın alt tarafinda yeni iki bina ilave edildi. 1969-1970 y1llarında dershaneler ve okul idaresi buraya taşındı. Asıl saray binası ise sadece yatakhane olarak kullanıldı. 1986 yılı Mart ayının ilk günlerinde geceleyin zuhur eden bir yangınla bina tamamen yandı. Bu yangınla birlikte bina içindeki pek çok kıymetli eşya ve özellikle de büyük aynalar da yok oldu. Bugün Âdile Sultan Sarayı'ndan sadece kâgir dış duvarlar kalmıştır ${ }^{82}$.

80 Afife Batur, “Âdile Sultan Sarayı”, Dünden Bugüne İstanbul Ansiklopedisi, I, Haz. İlhan Tekeli vd., İstanbul 1993, s. 85.

81 Osman Nuri Ergin, Türkiye Maarif Tarihi, Cilt, 3-4, İstanbul 1977, s. 1428-1429

82 Semavi Eyice, “Âdile Sultan Sarayı”, DlA, I, s. 383-384. 


\section{Salıpazarı Sahilsarayı}

Fındıklı ile Salıpazarı arasında bulunmaktadır. Abdülmecid'in kardeşi Âdile Sultan ile kızları Cemile ve Münire sultanlar için yaptırdığı saraylara "Salıpazarı Sahilsarayları" denmektedir ${ }^{83}$. Münire Sultan 1862 yılında vefat ettikten sonra, evvela Sultan Abdülaziz'in kızlarından Saliha Sultan, daha sonra da Âdile Sultan bu sarayda ikamet etmişlerdir. Âdile Sultan'ın Fındıklı'da bulunan ve gelin olarak gelip uzun süre ikamet ettiği saray "Âdile Sultan Sarayı” olarak anılmıştır. Âdile Sultan son nefesini bu sarayda vermiştir. Âdile Sultan'ın 1899'da vefat etmesi ile saray, Ahmed Zülküf Paşa'ya (Abdülaziz'in damadı) geçmiştir. Yap1, Cumhuriyetten sonra bir süre III. Kolordu Komutanlığ1 Karargâhı olarak hizmet vermiştir. 1943-1952 yılları arasında edebiyat fakültesi olarak, bu tarihten 1970 yılına kadar Atatürk Kız Lisesi olarak kullanılan saray, bu tarihten sonra Mimar Sinan Üniversitesi'ne devredilmiştir ${ }^{84}$.

\section{Kuruçeşme Sahilsarayı}

Birinci Abdülhamid'in kızı Esma Sultan'ın Beşiktaş ile Ortaköy arasinda bulunan Defterdar Burnu'ndaki sahilsarayı, ölümünden sonra yeğeni Âdile Sultan'a bırakılmıştır ${ }^{85} .1908$ yılında Kabataş İdadi Mektebi burada eğitime başlamış ve 1923'te Kabataş Erkek Lisesi adını almıştır. Günümüzde saraydan iz kalmamıştır ${ }^{86}$.

\section{Sultanın Vefatı}

Âdile Sultan oldukça uzun bir hayat yaşamıştır. İkinci Mahmud, Abdülmecid, Abdülaziz, Beşinci Murad ve Sultan İkinci Abdülhamid dönemlerini görmüştür. İkinci Abdülhamid Âdile Sultanı çok severmiş. Onunla hususi olarak ilgilenir ve "halacı̆̆ım" diye konuşur, âdile Sultan da ona "oğlum" diye hitap edermiş ${ }^{87}$. Sultan İkinci Abdülhamid'in

83 Mazak, a.g.e., s. 63.

84 Tunca Özgişi, “Osmanlı'da Bir Kadın Eğitim Gönüllüsü: Âdile Sultan”, Uluslararası Sosyal Araştırmalar Dergisi, Cilt: 6 Sayı: 26, Bahar 2013, s. 466.

85 Esma Sultan, Âdile Sultan'ın halasıdır.

86 Mazak, a.g.e., s. 61-62.

87 Çağatay Uluçay, a.g.e., s. 137. 
kızı Ayşe Sultan hatıralarında babasıyla Âdile Sultanın ilişkilerini şöyle anlatır:

"Ölümünden sonra saraya gelen câriyeleri ve ağaları, efendilerinin hikâyelerini, iyiliğini bize anlatırlarken gözyaşlarını zaptedemezlerdi... Babamla görüşmek istediği zaman haber gönderir, sarayda husûsî hazırlıklar yapılır, bu suretle saraya gelirdi. Babam hürmet ve tazimle halasının elini öper, büyük kanepeye halasını oturtup kendisi de karşısına otururdu. Hazînedârlar, askılar içinde kahvesini getirirler, babam eliyle tepsiden alıp halasına verirdi... Bizler içeriye girip elini öper, yerden bir temenna ederek Pâdişâh'a yaptı̆̆ımız resmî tazimi ifâ eder, çıkardık. Babama, oğlum hitabında bulunur, babam da kendisine; "Emredersiniz halacı̆̆ım" cevâbını verirdi. Konuşma bir-iki saat kadar devam eder, yine geldiği gibi arabasına biner, babam da kapıya kadar kendisini teşŷ̂ ederdi.... Yüzünün eskiden pek güzel olduğu belliydi. Narin, orta boylu, kumral, mâvi-elâ gözlü, nûrânî, asaletini gösteren hâl, hareket ve terbiyeye mâlik bir sultand. Giyinmesi tamâmiyle alaturka olup, ağır kumaşlardan dört etekli entari, ayağına güderiden papuç giyer, beline şaldan kuşak bağlar, bu entari üzerine, salta dedikleri bol kollu bir ceket geçirir, başına fes gibi bir şey giyip etrafina oyalı ipekli yemeni sarar, üzerine zümrüt ve lâ'llerle yapılmış, ortadaki daha büyük, iki yanlarındakiler küçük, gül şeklinde kıymetli iğneler takardl. Başka hiç bir mücevher nişan takmazdl... ${ }^{88 "}$

Âdile Sultan, 1898 senesi Ocak ayının son günlerine rastlayan bir bayram sabahı 73 yaşında Fındıklı'da vefat etti. Sultanın naaşı kalabalık bir cemaat eşliğinde gerekli ihtimam ile Salıpazarında bulunan sahilsarayından kaldırılarak beş çifte bir kayığa konulup Hazreti Halid'deki iskeleye çıkarıldı. Sarayından Eyüp iskelesine gelinceye kadar gerek kayıkta ve gerek ona eşlik eden diğer kayıklarda müezzinler ve dervişler tarafından Kur'an-1 Kerim tilâvet edildi. Ayrıca buhurdanlardan da güzel kokular neşredildi. Padişah iradesi gereğince iskelede kâfi miktarda bahriyeli asker, birçok polis, belediye, jandarma dahi cenazeye eşlik etti. İskelede erkân-1 harbiyye müşiri Şakir Paşa

88 http://www.bizimsahife.org/Kutuphane/Osmanli_Tarihi_Ans/Osmanli_Tarihi_A/ 027_Adile_Sultan.htm 
ve maiyyeti, ser-kurenâ Hacı Ali Bey, zabtiye nazırı Şefik Bey, Liman kumandanı vekili Mehmed Paşa ve yüksek rütbeli bahriyeli zabitler hâzır bulunarak cenaze oradan el üzerinde Eyyüb-el-Ensâri Camiine ulaştırıldı. Cenazenin önünde bulunan dervişler ve saray müezzinleri ilahiler okudu. Yine cenaze alayında Enderun ağaları ve kavaslar vesaire hazır bulunmuşlard ${ }^{89}$.

Salıpazarı iskelesinden Eyüpsultan Camiine getirilen cenazenin, kalabalık bir cemaat tarafından namazı kılındı ve Sultan, gözyaşları arasında, sağlığında yaptırmış olduğu türbeye, eşinin yanına defnedil$\mathrm{di}^{90}$.

Fransızca Servet Gazetesinde çıkan habere göre de Âdile Sultan'ın vefatı padişahı fevkalade müteessir ve mahzun eylediğinden bayram günlerinde mızıka-i hümayun tarafından icrası geleneksel olan terennümler icra edilmedi ${ }^{91}$.

Vefat münasebetiyle pek çok kişi tarafından taziye için telgraflar çekilerek padişahın acısı paylaşılmış, bazı devlet erkânı ve yabanc1 devlet temsilcileri de aynı amaçla padişahın huzuruna çıkmışlardı. Bunlardan birisi de Rum Patriki idi. Patrik yanında biri daha olduğu halde saraya gelerek gerek kendisi ve gerek patrikhane namına Âdile Sultan'ın vefatından dolayı padişaha taziyelerini bildirmişlerdi ${ }^{92}$.

\section{Vefatın Basındaki Yankıları}

Son derece nazik, hayırsever, dindar ve şaire bir Sultanın vefatına her kesimden insanın üzüldüğüne, arkasından ağıtlar yakıldığına -hayat hikâyesi ve yaptıklarını gördükten sonra- şüphe yoktur. Dönemin basını da bu konuda sessiz kalmamıştır. 14 Şubat 1899 tarihli İkdam gazetesi Sultanın ölüm haberini okuyucularına ilk sayfadan duyurduğu gibi, vefatına şu dörtlükle bir de tarih düşmüştür.

89 İkdam Gazetesi, 14 Şubat 1899 Salı, Beşinci sene, no:1645, s. 1.

90 Elif Naci, aynı makale, s. 30-31; Âdile Sultanın türbesi Hüsrev Paşa türbesine bitişik olup, Bostan İskelesi Hüsrev Paşa Çeşmesi ve Hüsrev Paşa Kütüphanesinin karşısındadır. Yüksel Çelik, Şeyh’ül-Vüzera Koca Hüsrev Paşa, Ankara 2013, s. 452, 458.

91 İkdam Gazetesi, 14 Şubat 1899 Sal1, Beşinci sene, no:1645, s. 1.

92 BOA, Y.PRK.BŞK. 58/73. 
Oldu bir Sultân-1 Âlişân bugün makber-i güzîn

Dil nasıl etsün tahammül böyle mehcûriyete

Çıkdı bir âh-1 teessür söyledim tarihini

Etdi rihlet Âdile Sultan cihân-1 rahmete (1316)

Yine gazetede Sultanın vefatılla ilgili olarak adeta milletin hislerine, düşüncelerine tercüman olurcasına hakkında güzel şeyler ifade edilmiş ayrıca "izhar-1 matem" başlıklı şiir de yazılmıştı" .

\section{Âdile Sultan Türbesi}

Eyüp, Bostan İskelesi Caddesi'nde, Mahmud Celaleddin ve Efendi Hüsrev Paşa türbelerinin bulunduğu yapı grubunun bir bölümüdür. Âdile Sultan'ın adını taşıyan türbenin sultanın ölümünden oldukça önce inşa edilmiş olma ihtimali yüksektir. Buraya ilk önce eşi Mehmed Ali Paşa ile kızı Hayriye Hanım Sultan'ın defnedilmiş olmaları bu ihtimali daha da güçlü kılmaktadır.

Türbe dikdörtgen planlı olup, karşılıklı iki odadan ibaret bir ev görünümündedir. Kare odalar birer kubbe ile örtülüdür ve mezarlar bu bölümlerde bulunur. Yapının duvarlarında, 19. yüzyılın tipik barok tarzındaki kalem işleri bulunur. Ortadaki yuvarlak alınlıklı kapı ile pencerelerin demir parmaklıklarında da ince bezeme ve süsler vardır ${ }^{94}$.

\section{Değerlendirme ve Sonuç}

Sultan İkinci Mahmud ve Zernigar Kadın'ın çocuğu olarak 23 Mayıs 1826 'da dünyaya gele Adile Sultan, diğer hanedan çocukları gibi iyi bir eğitim aldı. Doğduğunda hem İstanbul'da hem de ülkenin Mısır gibi bazı bölgelerinde üç gün üçer nöbet top ve tüfenk atılarak ve akşamları da kandilleri yakılıp şehrayinlerle kutlamalar yapıldı. Sultan henüz dört yaşında iken annesi Zernigâr Kadın vefat etti.

Sultan İkinci Mahmûd'un emriyle kendi çocukları yaşamamış olan Nevfidan Kadın Adile Sultan'ı büyütmek ve yetiştirmek üzere görevlendirildi. O da Âdile Sultân'ı kendi evlâdı gibi büyütüp yetiştirdi ve iyi bir tahsil ve terbiye görmesini sağladı.

93 İkdam Gazetesi, 14 Şubat 1899 Salı, Beşinci sene, no:1645, s. 1.

94 Yıldız Demiriz, “Âdile Sultan Türbesi”, Dünden Bugüne İstanbul Ansiklopedisi, I, Haz. İlhan Tekeli vd., İstanbul 1993, s. 85. 
Âdile Sultan sarayda özel hocalardan Kuran-1 Kerim, Arapça, Farsça, musiki ve hat dersleri alarak yetişti. Bu eğitim süreci onun edebiyat ve şiire ilgi duymasını sağladı. Tabii olarak küçük yaşlarda annesini kaybetmiş olması da şiire merakında etkili oldu.

Aldığı bu eğitimler hassas kişiliği ile birleşince de bir şaire sultan olarak divan oluşturan şiirler de yazdı. Bu açıdan bakıldığında hanedan mensupları içinde divan sahibi tek kadın olarak tarihe geçti. On üç yaşına geldiğinde bu defa babası İkinci Mahmud'u kaybedince hem öksüz hem yetim kalan Adile Sultan'1 kendisini çok seven ağabeyi Abdülmecid kol kanat germeye başladı.

Adile Sultan hanedan mensubu diğer sultanların genelinde olduğu gibi siyasi bir evlilik yaptı. Sultan Abdülmecid, kız kardeşinin o sırada Tophane Müşiri olan Mehmed Ali Paşa ile evlenmesini uygun gördü. 1845 yılında da muhteşem bir düğünle evlendiler. Neşetâbâd Sarayı, evlendikten sonra Âdile Sultan'a tahsis edilse de, Kuruçeşme'deki yalıda, Kâğıthane, Çırağan, Validebağı ve Kandilli'deki saraylarda ikamet ettiği de oldu. Mehmed Ali Paşa 1868 yılında vefat etti. Âdile Sultan kocasını, Mehmed Ali Paşa da sultanı sevdi. Sıdıka, Aliye, İsmail ve Hayriye isimlerinde dört çocukları oldu fakat bunlardan ilk üçü fazla yaşamadı.

İkinci Mahmud, Abdülmecid, Abdülaziz, Beşinci Murad ve Sultan İkinci Abdülhamid dönemlerini görmüş olan Âdile Sultan, hanedan mensubu diğer kadınlarla kıyaslandığında oldukça uzun bir hayat yaşadı. 1898 senesi Ocak ayının son günlerine rastlayan bir bayram sabahı 73 yaşında vefat etti. Kalabalık bir cemaat tarafindan Eyüpsultan Camiinde cenaze namazı kılınan Sultan, sağlığında yaptırmış olduğu türbeye, eşinin yanına defnedildi. 


\section{Kaynakça}

\section{Arșiv Belgeleri}

BCA, 30-10-0-0_198-355-6.

BOA, HAT. 1642/9

BOA, HAT. 524/25608

BOA, HAT. 290/17398.

BOA, Y.MTV. 70/72.

BOA, Y.PRK.A. 2/34.

BOA, Y.PRK.BŞK. 58/73.

BOA, Y.PRK.ZB. 10/76

BOA, Y.PRK.ZB. 6/49.

\section{Gazeteler}

Cumhuriyet (05.10.1961)

İkdam (14 Şubat 1899 Salı, no:1645)

Star (07.12.2014)

\section{Telif Eserler}

"Âdile Sultan", İstanbul Ansiklopedisi-I, (Haz. Reşat Ekrem Koçu), İstanbul 1958.

Akalın Erkan, "Bir Saray Sözcüsü Olarak Klasik Türk Şiiri”, Turkish Studies, 9/9, Yaz 2014.

Akyıldız Ali, Mümin ve Müsrif Bir Padişah Kızı Refia Sultan, Tarih Vakf1 Yurt Yayın1, İstanbul 1998.

Ali Rıza-Mehmed Galib, Geçen Asırda Devlet Adamlarımız-I, (XVIII. Asr-ı Hicride Osmanlı Ricali), İstanbul 1977.

Ali Seydi Bey, Teşrifat ve Teşkilatımız, (Haz. Niyazi Ahmed Banoğlu), Tercüman Yayınları, İstanbul, ty.

Artuk İbrahim, "Nişan”, DİA, XXXIII, y1l: 2007.

Atalan Özlem, "Ortaköy-Kuruçeşme Arasındaki Sahilsaraylar; 19. Yüzyıl”, Turkish Studies, Volume 10/1 Winter 2015.

Azamat Nihat, “Âdile Sultan” DİA, I, y1l: 1988, s. 382.

Balıkhane Nazırı Ali Rıza Bey, Eski Zamanlarda İstanbul Hayat, (Haz. Ali Şükrü Çoruk), İstanbul 2001.

Batur Afife, “Âdile Sultan Kasrı”, Dünden Bugüne İstanbul Ansiklopedisi, I, Haz. İlhan Tekeli vd., İstanbul 1993. 
Batur Afife, “Âdile Sultan Saray1”, Dünden Bugüne İstanbul Ansiklopedisi, I, Haz. İlhan Tekeli vd., İstanbul 1993.

Bayraktar Nail, Âdile Sultan, TSM Sevenler Derneği, Sanat Tarihi Araştırmaları Semineri, İstanbul 1994.

Beydilli Kemal, "Mahmud II”, DIA, XXVII, y1l: 2003.

Beydilli Kemal, "Mahmud II”, DIA, XXVII, y1l: 2003.

Beydilli Kemal, "Mehmed Emin Rauf Paşa”, DİA, XXVIII.

Buzpınar Tufan, “Altunizâde Ailesi”, Üsküdar Sempozyumu, IV, cilt:2, Edt. Coşkun Yılmaz, İstanbul 2007.

Çakır Zeynep, "Şiirleriyle Tarih Yazan Bir Saraylı: Âdile Sultan”, Yeni Asya, 11 Haziran 2011.

Çelik Yüksel, Şeyh'ül-Vüzera Koca Hüsrev Paşa, Ankara 2013.

Demiriz Y1ldız, “Âdile Sultan Türbesi”, Dünden Bugüne İstanbul Ansiklopedisi, I, Haz. İlhan Tekeli vd., İstanbul 1993.

Ergin Osman Nuri, Türkiye Maarif Tarihi, Cilt, 3-4, İstanbul 1977.

Erginer Suat, Asya'nın Kapısı Üsküdar, İstanbul 1966.

Eyice Semavi, “Âdile Sultan Sarayı”, DlA, I, s. 383-384.

Eyice Semavi, “Âdile Sultan Namazgâhı”, Dünden Bugüne İstanbul Ansiklopedisi, I, Haz. İlhan Tekeli vd., İstanbul 1993.

Haskan Mehmet Mermi, Yüzylllar Boyu Üsküdar, III, İstanbul 2001.

Haskan Mehmet Mermi, Yüzyıllar Boyunca Üsküdar, III, İstanbul 2001.

İnal İbnülemin Mahmud Kemal, Son Sadrazamlar, Cilt 1, Dergâh yayınları, İstanbul 1982.

Kutlu Murat, "Avrupalıları Hayran Bırakan Neşetâbâd Sarayı”, Star Gazetesi, 07.12.2014.

Masak Ferda, “Âdile Sultan'ın Üsküdar'da Yaşadığı Mekânlar, Vakıfları ve Bugünkü Durumları”, Üsküdar Sempozyumu-I, Cilt II (Edt: Zekeriya Kurşun vd), İstanbul 2004.

Mazak Ferda, Sultan II. Mahmud'un Kızı Âdile Sultan, Çamlıca Kültür ve Yardım Vakfı Yayını, İstanbul 2000.

Mehmed Süreyya, Sicill-i Osmânî, I, (Yay. Haz. Nuri Akbayar), İstanbul 1996. 
Mehmed Süreyya, Sicill-i Osmânî, III, (Yay. Haz. Nuri Akbayar), İstanbul 1996.

Naci Elif, “Türk Sarayında Müstesna Bir Prenses: Âdile Sultan”, Hayat Tarih Mecmuası, Say1 10, Kasım 1965.

Özcan Abdülkadir, "II. Mahmud ve Reformları Hakkında Bazı Gözlemler", Tarih İncelemeleri Dergisi, X, İzmir 1995.

Özgişi Tunca, “Osmanlı'da Bir Kadın Eğitim Gönüllüsü: Âdile Sultan”, Uluslararası Sosyal Araştırmalar Dergisi, Cilt: 6 Sayı: 26, Bahar 2013.

Özgüven Burcu, "Mahmud II Türbesi, Sebili, Çeşmesi ve Hazîresi”, DIA, XXVII, y1l: 2003.

Öztuna Y1lmaz, Devletler ve Hanedanlar II-Türkiye 1074-1990, C.I, Kültür Bakanlığ 1 , Ankara 1996.

Sakaoğlu Necdet, "Beşik Alayı”, Dünden Bugüne İstanbul Ansiklopedisi, II, s. 160.

Şesuvaroğlu Haluk Y., "Garp Kaynaklarına Göre Boğaziçi”, Cumhuriyet Gazetesi, 05.10.1961.

Tanman M. Baha, “Âdile Sultan Mektebi”, Dünden Bugüne İstanbul Ansiklopedisi, I, Haz. İlhan Tekeli vd., İstanbul 1993.

Uluçay M. Çağatay, Padişahların Kadınları ve Kızları, Ankara 2001.

\section{Web Sayfaları}

http://www.bizimsahife.org/Kutuphane/Osmanli_Tarihi_Ans/Osmanli_Tarihi_A/027_Adile_Sultan.htm

http://www.ekrembugraekinci.com/makale.asp?id=332

Hikmet Özdemir, “Âdile Sultan'ın Şairliği ve Edebî Kişiliği”, http:// www.hikmetozdemir.com.tr. 